Wanastra : Jurnal Bahasa dan Sastra

Volume 12 No. 2 September 2020

P-ISSN 2086-6151 E-ISSN 2579-3438

https://doi.org/10.31294/w.v12i1

\title{
Kesalahan Ejaan dan Kesalahan Penulisan Kalimat dalam Surat Izin Siswa
}

\author{
Syamsul Ghufron $^{1}$, Lia Fitri Sri Adiyati ${ }^{2}$, Markub $^{3}$ \\ ${ }^{1}$ Universitas Nahdlatul Ulama Surabaya \\ e-mail: ${ }^{1}$ syamsulghufron@unusa.ac.id \\ ${ }^{2}$ Madrasah Ibtidaiyah Negeri 2 Lamongan \\ e-mail : ${ }^{2}$ liafitrisriadiyati@gmail.com \\ ${ }^{3}$ Universitas Islam Darul Ulum Lamongan \\ e-mail: ${ }^{3}$ maskub@unisda.ac.id,
}

\begin{tabular}{ccc}
\hline Diterima & Direvisi & Disetujui \\
$10-08-2020$ & $01-09-2020$ & $03-09-2020$ \\
\hline
\end{tabular}

\begin{abstract}
Abstrak - Penelitian ini bertujuan untuk mendeskripsikan kesalahan ejaan dan kesalahan penulisan kalimat dalam surat izin siswa MTs Al-Muslimun Kawistolegi. Penelitian ini tergolong penelitian deskriptif kualitatif. Data penelitian ini adalah kesalahan ejaan dan kesalahan penulisan kalimat dalam surat izin siswa MTs Al-Muslimun Kawistolegi. Pengumpulan data dalam penelitian ini menggunakan teknik tes, teknik simak, dan teknik catat dengan instrumen penelitian berupa soal tes perintah menulis surat izin kepada siswa dan lembar korpus data. Metode simak adalah cara yang digunakan untuk memperoleh data dilakukan dengan menyimak penggunaan bahasa. Hasil penelitian menunjukkan hal-hal sebagai berikut. Dalam surat izin siswa MTs Al-Muslimun Kawistolegi terdapat kesalahan ejaan berupa kesalahan penulisan kata dasar, kesalahan pemakaian huruf kapital, kesalahan penulisan kata depan, kesalahan penulisan singkatan, dan kesalahan pemakaian tanda baca titik dan koma. Kesalahan kalimat yang ditemukan dalam penelitian ini adalah kalimat tidak gramatikal karena tidak adanya subjek dan predikat dan kalimat tidak hemat karena adanya kata yang tidak jelas fungsinya serta adanya dua kata yang sama maknanya sama.
\end{abstract}

Kata Kunci: kesalahan ejaan, kesalahan kalimat, surat izin, siswa

Abstract - This study aims to describe the spelling and sentence errors in the permission of students of MTs AlMuslimun Kawistolegi. This research is classified as a qualitative descriptive study. The data of this study are spelling errors and sentence errors in the permission of students of MTs Al-Muslimun Kawistolegi. To collect data in this study, the researcher used the test techniques, listening techniques, and note-taking techniques with research instruments in the form of test questions to write permission letters to students and corpus data sheets. The method of listening is a method used to obtain data carried out by listening to the use of language. The results of the study indicate the following matters. In the MTs Al-Muslimun Kawistolegi student permit there are spelling errors in the form of errors in writing basic words, mistakes in the use of capital letters, mistakes in writing prepositions, mistakes in writing abbreviations, and errors in the use of punctuation marks and commas. Sentence errors found in this study are non-grammatical sentences because there are no subjects and predicates and sentences are not economical because of the existence of words with unclear functions and the existence of two words with the same meaning.

Keywords: spelling mistakes, sentence errors, permission letters, students

\section{PENDAHULUAN}

Sebagai makhluk sosial, manusia membutuhkan sarana untuk berinteraksi dengan manusia lainnya. Sarana itu di antaranya adalah bahasa. Bahasa adalah alat komunikasi antara anggota masyarakat berupa simbol bunyi yang dihasilkan oleh alat ucap manusia (Keraf, 2004:1). Salah satu fungsi bahasa ialah sebagai alat komunikasi dan sarana berpikir. Menurut Tarigan (2008:19), komunikasi merupakan proses pengiriman dan penerimaan pesan-pesan yang pasti terjadi sewaktu-waktu bila manusia atau binatangbinatang ingin berkenalan dan berhubungan.

Salah satu sarana penyampaian pesan atau informasi dengan media tulis adalah surat. Informasi dalam surat dapat berupa pemberitahuan, pernyataan, permintaan, perizinan, dan lain-lain. Dengan kata lain, surat merupakan alat komunikasi yang berbentuk tulisan digunakan untuk berbagai keperluan.

Jika tidak dapat masuk sekolah, seorang siswa pun harus membuat surat izin yang 
disampaikan kepada gurunya. Surat izin siswa merupakan surat yang ditulis siswa untuk meminta izin jika tidak bisa masuk sekolah. Surat izin siswa ditulis untuk disampaikan kepada guru kelas dengan harapan mendapat izin yang dimaksudkan.

Dalam K-13, pembelajaran menulis surat untuk siswa SMP kelas VII ada di KD 4.12 Menulis surat (pribadi dan dinas) untuk kepentingan resmi dengan memperhatikan struktur teks, kebahasaan, dan isi. Dari kompetensi dasar tersebut, jelas siswa SMP/MTs harus mampu menulis surat pribadi maupun dinas.

Kenyataan menunjukkan bahwa hasil pembelajaran menulis surat oleh siswa MTs. AlMuslimun sangat mengecewakan. Rata-rata nilai yang diperoleh siswa yakni 64, sedangkan KKM mata pelajaran Bahasa Indonesia adalah 70. Tidak tercapainya KKM dalam pembelajaran menulis surat di antaranya disebabkan oleh masih terdapatnya kesalahan berbahasa dalam surat yang mereka tulis.

Penulisan surat izin oleh siswa sering memunculkan kesalahan berbahasa. Kesalahan berbahasa yang dimaksudkan adalah sebagai bentuk penyimpangan bahasa dari sistem atau kebiasaan berbahasa umumnya pada suatu bahasa sehingga menghambat kelancaran komunikasi berbahasa (Ghufron, 2015:2). Kesalahan berbahasa mengganggu pencapaian tujuan pembelajaran bahasa. Oleh sebab itu, kesalahan berbahasa yang sering dibuat siswa harus dikurangi dan dihapuskan. Kesalahan itu biasanya ditentukan berdasarkan kaidah atau aturan yang berlaku dalam bahasa yang sedang dipelajari. Jika penulisan kata, pemilihan kata, dan kalimat yang digunakan siswa atau pembelajar tidak sesuai dengan kaidah yang berlaku, maka pembelajar bahasa dikatakan membuat kesalahan.

Memang dalam karangan siswa baik siswa SD, siswa SMP, maupun siswa SMA masih banyak ditemukan kesalahan. Hal tersebut terbukti dari penelitian Ghufron (2017) yang menemukan kesalahan berbahasa dalam tulisan siswa SD (kesalahan pemakaian ejaan, kesalahan pemilihan kata, dan kesalahan penyusunan kalimat) dan penelitian Apriliana \& Martini (2018) yang menemukan kesalahan ejaan dalam karangan narasi siswa SD. Begitu juga hasil penelitian Ayudia et al., (2017) yang menemukan kesalahan berbahasa dalam laporan hasil observasi siswa SMP yang meliputi kesalahan ejaan, kesalahan diksi, kesalahan penyusunan kalimat, dan kesalahan paragraf serta penelitian Hamlan \& Karim (2018) yang menemukan kesalahan penulisan karangan deskripsi siswa SMP yang meliputi kesalahan penulisan kata, penggunaan kata depan, penggunaan singkatan, penggunaan kata ulang, penggunaan tanda hubung dan kesalahan penggunaan imbuhan. Selain itu, hasil penelitian Ariningsih et al. (2012) menemukan kesalahan bahasa dalam karangan siswa SMA: kesalahan ejaan, kesalahan diksi, kesalahan kalimat, dan kesalahan paragraf dan penelitian Fajarya (2017) juga menemukan kesalahan penggunaan ejaan dalam karangan siswa SMA.

Begitu juga dalam karangan siswa yang berbentuk surat izin, ketepatan kaidah dalam penulisan surat izin dari segi kebahasaannya sering kali diabaikan, seakan-akan masalah ketepatan tersebut dianggap tidak perlu diperhatikan. Surat izin yang dibuat siswa kadang-kadang tidak jelas maksudnya. Ketidakjelasan itu disebabkan oleh kesalahan atau ketidaktepatan penggunaan bahasa. Hal ini dapat terjadi karena penulis kurang paham terhadap kaidah-kaidah kebahasaan atau bisa juga terjadi karena hal-hal lain yang sifatnya kurang teliti dan sebagainya. Bahasa surat izin seharusnya memiliki susunan kalimat singkat, cermat, tepat dalam menggunakan pilihan kata dan ejaan agar mudah dipahami. Menulis surat izin bukanlah hal yang mudah dilakukan oleh setiap siswa, khususnya pada siswa MTs di sekolah tertentu.

Penulisan surat izin di MTs Al-Muslimun masih banyak ditemukan kesalahan seperti kesalahan penulisan kata dasar, kesalahan pemakaian huruf kapital, kesalahan penulisan kata depan, kesalahan penulisan singkatan, kesalahan pemakaian tanda baca, dan kesalahan penyusunan kalimat. Kesalahan-kesalahan tersebut terjadi karena faktor kompetensi. Faktor kompetensi adalah kesalahan yang disebabkan siswa belum memahami sistem linguistik bahasa yang digunakan. Kebutuhan surat izin dalam kehidupan sehari-hari siswa sangatlah penting. Karena itu, peneliti tertarik mengadakan penelitian terhadap surat izin. Peneliti ingin melihat kesalahan ejaan dan kesalahan kalimat yang digunakan dalam penulisan surat izin siswa.

Uraian di atas memunculkan permasalahan tentang penggunaan bahasa Indonesia yang baik dan benar dalam surat izin siswa. Apakah surat yang telah ditulis tersebut sudah mengacu pada kaidah bahasa Indonesia sehingga dapat dijadikan bahan pembelajaran untuk meningkatkan kemampuan berbahasa Indonesia baik secara lisan atau tulis, terutama pada penulisan surat izin siswa. Karena itu, peneliti memilih judul penelitian Kesalahan Ejaan dan Kesalahan Kalimat dalam Surat Izin Siswa MTs Al-Muslimun Kawistolegi, Lamongan. Penelitian ini bertujuan untuk mendeskripsikan kesalahan ejaan dan kesalahan kalimat dalam surat izin siswa MTs Al-Muslimun Kawistolegi.

\section{METODE PENELITIAN}


Penelitian ini tergolong penelitian deskriptif kualitatif. Penelitian deskriptif merupakan metode yang digunakan untuk menggambarkan atau menganalisis suatu hasil penelitian (Sugiyono, 2017:21). Metode penelitian kualitatif adalah metode yang digunakan untuk meneliti pada kondisi objek yang alamiah. Berdasarkan konsep tersebut, penelitian ini adalah penelitian kualitatif yang bersifat deskriptif dengan alasan (1) data dalam penelitian ini berupa kesalahan berbahasa yang bersumber dari tulisan surat izin siswa MTs. AlMuslimun Kawistolegi dan (2) data yang disajikan dalam penelitian ini berupa kata-kata bukan angkaangka.

Data adalah hasil pencatatan peneliti, baik berupa fakta ataupun angka (Arikunto, 2013:161). Data penelitian ini adalah kesalahan ejaan dan kesalahan penulisan kalimat dalam surat izin siswa MTs. Al-Muslimun Kawistolegi. Data dalam penelitian kesalahan berbahasa seperti ini dapat berupa data lisan dan data tertulis (Ghufron, 2015:80). Data yang dikumpulkan dalam penelitian ini berupa data tertulis.

Adapun sumber datanya berupa surat izin siswa kelas VII MTs. Al-Muslimun Kawistolegi. Kelas VII terbagi menjadi tiga kelas yaitu VIIA, VIIB, dan VIIC. Namun dalam penelitian ini peneliti hanya mengambil dua kelas yakni kelas VIIB dan VIIC dengan jumlah 44 siswa terdiri atas 25 siswa laki-laki dan 19 siswa perempuan.

Pengumpulan data dalam penelitian ini menggunakan teknik tes, teknik simak, dan teknik catat dengan instrumen penelitian berupa soal tes perintah menulis surat izin kepada siswa dan lembar korpus data. Metode simak adalah cara yang digunakan untuk memperoleh data dilakukan dengan menyimak penggunaan bahasa (Mahsun, 2012:29). Dalam penelitian ini, hasil tes terkumpul berupa surat izin yang ditulis siswa. Selanjutnya, peneliti menggunakan teknik simak untuk menyimak secara seksama kesalahan ejaan dan kesalahan kalimat dalam penulisan surat izin siswa.

Teknik analisis data yang digunakan dalam penelitian ini adalah teknik analisis data kualitatif yang meliputi reduksi data, penyajian data, dan penyimpulan.

Sugiyono (2017:335) menyatakan bahwa teknik analisis merupakan upaya mencari dan menyusun secara sistematis data yang diperoleh dari hasil wawancara, catatan lapangan, dan dokumentasi. Teknik analisis data dalam penelitian ini meliputi reduksi data, penyajian data, dan verifikasi/kesimpulan. Adapun prosedur analisis data kesalahan berbahasa ini meliputi (1) mengidentifikasi kesalahan berbahasa, (2) mengklasifikasikan kesalahan berbahasa atas kesalahan ejaan dan kesalahan kalimat, (3) menjelaskan kesalahan berbahasa, (4) merevisi kesalahan berbahasa, dan (5) menyimpulkan hasil penelitian berupa kesalahan ejaan dan kesalahan kalimat dalam surat izin siswa MTs. Al-Muslimun Kawistolegi.

\section{HASIL DAN PEMBAHASAN}

Sesuai dengan tujuan penelitian, hasil penelitian ini terbagi atas dua bagian yakni kesalahan ejaan dan kesalahan kalimat dalam Surat Izin Siswa MTs. Al-Muslimun Kawistolegi.

\section{Kesalahan Ejaan dalam Surat Izin Siswa}

Kesalahan ejaan yang ditemukan dalam penelitian ini diklasifikasikan atas 5 macam yakni kesalahan penulisan kata dasar, kesalahan pemakaian huruf kapital, kesalahan penulisan kata depan, kesalahan penulisan singkatan, dan kesalahan pemakaian tanda baca. Pedoman yang digunakan dalam menentukan kesalahan ejaan adalah Pedoman Umum Ejaan Bahasa Indonesia (Sugiyono, 2016).

\section{a. Kesalahan Penulisan Kata Dasar}

Benar atau salahnya penulisan kata dasar didasarkan pada penulisan kata dasar yang terdapat dalam Kamus Besar Bahasa Indonesia (Ghufron, 2015:103). Penulisan kata dasar yang salah dalam surat izin siswa MTs. Al-Muslimun Kawistolegi dapat diamati pada data-data di bawah ini.

(1) bahwah (05/E/AAF)

(2) jum'at (11E/AAP)

(3) $\operatorname{kasian}(28 / \mathrm{E} / \mathrm{NUM})$

(4) karna (43/E/ZAP)

Data (1)-(4) merupakan penulisan kata dasar yang salah. Penulisan kata tersebut salah karena penulisan kata tersebut tidak sesuai dengan kata dasar yang terdapat dalam Kamus Besar Bahasa Indonesia. Kesalahan tersebut adalah kesalahan penulisan yang terjadi karena huruf-huruf yang tertulis pada kata dasar tidak lengkap atau tidak sesuai dengan kata dasar yang terdapat dalam Kamus Besar Bahasa Indonesia. Kata bahwah, jum'at, kasian, karna tidak terdapat dalam $K B B I$.

Dengan demikian, kata-kata pada data (1)—(4) seharusnya ditulis sebagai berikut.

(1a) bahwa

(2a) Jumat 
(3a) kasih

(4a) karena

\section{b. Kesalahan Pemakaian Huruf Kapital}

Kesalahan pemakaian huruf kapital dalam surat izin siswa MTs. Al-Muslimun Kawistolegi dapat diamati pada data-data di bawah ini.

(5) mei (01/E/ADP)

(6) ALFIN ALDIN FEBRIANSYAH (05/E/AAF)

(7) dengan surat izin ini saya memberitahukan bahwa ... (10/E/ARM)

(8) kawistolegi (12/E/AMV)

(9) MTs almusimun (26/E/NPA)

Data (5) merupakan penulisan huruf kapital yang salah berdasarkan PUEBI yang berbunyi, "Huruf kapital dipakai sebagai huruf pertama nama tahun, bulan, hari, dan hari besar atau hari raya." Kata "mei" seharusnya ditulis "Mei". Data (6) merupakan penulisan huruf kapital yang salah berdasar pada PUEBI yang berbunyi, "Huruf kapital digunakan pada huruf pertama setiap kata nama orang". Nama "ALFIN ALDIN FEBRIANSYAH" seharusnya ditulis "Alfin Aldin Febriansyah". Data (7) merupakan penulisan huruf kapital yang salah berdasarkan PUEBI yang berbunyi, "Huruf kapital dipakai sebagai huruf pertama awal kalimat". Kalimat "dengan surat izin ini saya memberitahukan bahwa ...." seharusnya ditulis "Dengan surat izin ini saya memberitahukan bahwa ..." Data (8) merupakan penulisan huruf kapital yang salah didasarkan pada PUEBI yang berbunyi, "Huruf kapital dipakai sebagai huruf pertama nama geografi." Kata "kawistolegi" seharusnya ditulis "Kawistolegi". Data (9) merupakan penulisan huruf kapital yang salah didasarkan pada PUEBI yang berbunyi, "huruf kapital dipakai sebagai huruf pertama semua kata dalam nama negara, lembaga, badan, organisasi, atau dokumen, kecuali kata tugas, seperti di, ke, dari, dan, yang, dan untuk". Nama "MTs almuslimun" seharusnya ditulis "MTs AlMuslimun".

Dengan demikian, data 5-9 di atas seharusnya diperbaiki penulisannya seperti $5 a-9 a$ berikut.

(5a) Mei

(6a) Alfin Aldin Febriansyah

(7a) Dengan surat izin ini saya memberitahukan bahwa.... (8a) Kawistolegi

(9a) MTs. Al-Musimun

\section{c. Kesalahan Penulisan Kata Depan}

Dalam Sugiyono (2016:24) disebutkan bahwa kata depan, seperti di, ke, dan dari, ditulis terpisah dari kata yang mengikutinya. Berdasarkan pedoman itu, ditemukan kesalahan penulisan kata depan di antaranya sebagai berikut.
(10) keSby (01/E/ADP)
(11) dikelas (15/E/DAP)
(12) $\mathrm{keWbl}(24 / \mathrm{E} / \mathrm{MAL})$
(13) $\operatorname{kerumah}(25 / \mathrm{E} / \mathrm{MTF})$

Keempat data di atas merupakan penulisan kata depan yang salah karena menyimpang dari PUEBI. Penulisan kata depan tersebut harus diubah seperti berikut.

(10a) ke Surabaya

(11a) di kelas

(12a) ke Wisata Bahari Lamongan

(13a) ke rumah

\section{d. Kesalahan Penulisan Singkatan}

Kesalahan penulisan singkatan dalam penelitian dapat diamati pada data-data di bawah ini.

(14) $\mathrm{YTH}(01 / \mathrm{E} / \mathrm{ADP})$

(15) Wasalamualaikum wr wb (05/E/AAF)

(16) Ahmad Alif .N.K (02/E/AAN)

Data (14) dan (15) merupakan penulisan singkatan yang salah berdasarkan PUEBI yang berbunyi, "Singkatan yang terdiri atas tiga huruf atau lebih diikuti dengan tanda titik." Singkatan "YTH" dan "Wasalamualaikum wr wb" seharusnya ditulis "Yth." dan "Wasalamualaikum war. Wab.". Data (16) merupakan penulisan singkatan yang salah berdasarkan PUEBI yang berbunyi, Singkatan nama orang, gelar, sapaan, jabatan, atau pangkat diikuti dengan tanda titik. Singkatan pada nama "Ahmad Alif .N.K” seharusnya ditulis "Ahmad Alif N.K.".

Berdasarkan hasil analisis data di atas pembenaranya dapat diamati sebagai berikut.

(14a) Yth.

(15a) Wasalamualaikum war. wab. 
(16a) Ahmad Alif N.K.

\section{e. Kesalahan Pemakaian Tanda Baca}

Kesalahan pemakaian tanda baca yang ditemukan dalam penelitian ini meliputi kesalahan pemakaian tanda titik dan kesalahan pemakaian tanda koma.

\section{1) Kesalahan Pemakaian Tanda Titik}

Berikut ini beberapa kesalahan pemakain tanda titik dalam surat izin siswa.

(17) Atas izinnya kami ucapkan terima kasih (01/E/ADP)

(18) Cuma itu yang saya sampaikan mohon maaf sebesar-besarnya (08/E/ATS)

(19) Untuk itu kami mohon izinnya sampai sembuh (25/E/MTF)

(20) Demikian surat ini saya berikan kepada ibu guru mohon dimaklumi (41/E/YDW)

Pada keempat data kalimat di atas terdapat kesalahan pemakaian tanda titik berdasarkan PUEBI yang berbunyi, "Tanda titik digunakan untuk mengakhiri kalimat kecuali kalimat perintah, kalimat Tanya, dan kalimat seru." Kalimat-kalimat tersebut seharusnya ditulis seperti berikut.

(17a) Atas izinnya, kami ucapkan terima kasih.

(18a) Hanya itu yang dapat saya sampaikan, mohon maaf.

(19a) Untuk itu, kami mohon izinnya sampai sembuh

(20a) Demikian surat ini saya berikan kepada Ibu guru, mohon dimaklumi.

\section{2) Kesalahan Pemakaian Tanda Koma}

Kesalahan pemakaian tanda baca yang ditemukan dalam penelitian ini meliputi kesalahan pemakaian tanda titik,

(21) atas izinnya kami ucapkan terima kasih. (01/E/ADP)

(22) kawistolegi $03 \quad$ mei 2018 (05/E/AAF)

(23) dengan ini ,saya ,orangtua ,Lidia memohon izin pada bapak atau ibu guru .... (18/E/LIV)
Pada data (21) terdapat pemakaian tanda koma yang salah berdasarkan PUEBI yang berbunyi, "Tanda koma dapat dipakai di belakang keterangan yang terdapat pada awal kalimat untuk menghindari salah baca/salah pengertian." Bagian yang menjadi keterangan pada data (21) adalah "atas izinnya". Karena itu, bagian tersebut seharusnya diikuti tanda koma sehingga menjadi "Atas izinnya, kami ucapkan terima kasih."

Pada data (22) terdapat pemakaian tanda koma yang salah berdasarkan PUEBI yang berbunyi, "Tanda koma dipakai di antara tempat dan tanggal." Penulisan yang benar data (22) adalah "Kawistolegi, 3 Mei 2018".

Pada data (23) terdapat pemakaian tanda koma yang salah berdasarkan PUEBI yang berbunyi, "Tanda koma dipakai di antara unsur-unsur dalam suatu pemerincian atau pembilangan". Pada data (23) di atas terdapat unsur-unsur pemerincian yakni saya, orang tua, dan Lidia. Karena itu, penulisan kalimat (23) tersebut yang benar adalah "Dengan ini saya, orang tua, Lidia memohon izin kepada Bapak atau Ibu Guru." Penulisan tanda koma mengikuti kata sebelumnya secara langsung tanpa spasi.

Berdasarkan paparan tentang kesalahan ejaan tersebut dapat disimpulkan bahwa dalam surat izin siswa MTs Al-Muslimun Kawistolegi terdapat kesalahan ejaan berupa kesalahan penulisan kata dasar, kesalahan pemakaian huruf kapital, kesalahan penulisan kata depan, kesalahan penulisan singkatan, dan kesalahan pemakaian tanda baca titik dan koma.

Temuan tersebut hampir sama dengan temuan Prasetya (2019) yang menyimpulkan adanya kesalahan ejaan pada surat dinas di STKIP Al Hikmah Surabaya berupa penggunaan huruf kapital, tanda koma, tanda titik dua. Jenis kesalahan pemakaian ejaan dalam penelitian ini lebih beragam daripada temuan Prasetya. Penelitian ini menemukan kesalahan penulisan kata dasar, kesalahan pemakaian huruf kapital, kesalahan penulisan kata depan, kesalahan penulisan singkatan, sedangkan Prasetya hanya menemukan kesalahan pemakaian huruf kapital. Untuk jenis kesalahan tanda baca yang ditemukan dalam penelitian ini berupa tanda baca titik dan koma, sedangkan Prasetya menemukan kesalahan tanda baca koma dan titik dua. Temuan yang berbeda ini dapat dimaklumi karena sumber data penelitian ini adalah surat izin yang ditulis siswa, sedangkan sumber data penelitian Prasetya adalah surat dinas/resmi suatu lembaga. Berdasarkan paparan tersebut, dapat disimpulkan bahwa kesalahan pemakaian ejaan pada penelitian ini dan penelitian Prasetya adalah pada kesalahan pemakaian huruf kapital dan kesalahan pemakaian tanda koma. 
Hasil penelitian Hamlan \& Karim (2018) menyimpulkan adanya kesalahan penulisan karangan deskripsi siswa SMP Negeri 1 Banawa yang meliputi kesalahan penulisan kata ulang, penggunaan kata depan, penggunaan singkatan, dan kesalahan penggunaan imbuhan. Jenis kesalahan pemakaian ejaan yang ditemukan Hamlan \& Karim ini memiliki kesamaan dengan hasil temuan penelitian ini pada kesalahan penulisan kata depan dan kesalahan penulisan singkatan.

Apriliana \& Martini (2018) menyimpulkan kesalahan ejaan meliputi kesalahan pemakaian huruf, kesalahan penulisan kata, dan kesalahan pemakaian tanda baca. Temuan penelitian Apriliana \& Martini ini sama persis dengan temuan penelitian ini karena jenis kesalahan yang ditemukan lebih sedikit dan bersifat umum sehingga kurang jelas. Kesalahan pemakaian huruf, kesalahan penulisan kata, dan kesalahan pemakaian tanda baca semuanya masih bersifat umum karena dalam PUEBI pemakaian huruf dibedakan atas huruf kapital, huruf miring, dan huruf tebal, penulisan kata dibedakan atas kata dasar, kata berimbuhan, bentuk ulang, gabungan kata, kata depan, partikel, singkatan dan akronim, angka dan bilangan, kata ganti, dan kata sandang.

Qhadafi (2018) menyimpulkan bahwa kesalahan ejaan dalam teks negosiasi siswa SMA Negeri 3 Palu meliputi kesalahan penggunaan huruf kapital, penggunaan huruf miring, penggunaan kata depan, penggunaan singkatan, dan penggunaan tanda baca (titik dan tanya). Temuan penelitian Qhadafi ini memiliki persamaan dengan temuan penelitian ini dalam hal kesalahan pemakaian huruf kapital, kesalahan penulisan kata depan, kesalahan penulisan singkatan, dan kesalahan pemakaian tanda titik. Perbedaannya terletak pada kesalahan pemakaian huruf miring dan pemakaian tanda tanya. Selain itu, adanya perbedaan penggunaan istilah "penggunaan" dalam penelitian Qhadafi yang seharusnya diganti dengan istilah "penulisan" karena objek kajian ejaan adalah penulisan bukan penggunaan.

Hasil penelitian Fajarya (2017) menyimpulkan bahwa bentuk kesalahan ejaan dibedakan menjadi enam aspek: kesalahan pemakaian huruf kapital, penggunaan kata berimbuhan, penggunaan kata depan, penggunaan unsur serapan, penggunaan tanda baca titik, dan penggunaan tanda baca koma. Persamaannya dengan penelitian ini adalah pada penemuan kesalahan pemakaian huruf kapital, penulisan kata depan, pemakaian tanda titik, dan pemakaian tanda koma. Perbedaannya terletak pada adanya penemuan kesalahan penggunaan kata berimbuhan, dan penggunaan unsur serpan. Istilah "penggunaan" pada penelitian Fajarya sebaiknya diganti "penulisan".
Penelitian Ghufron (2017) menyimpulkan bahwa kesalahan ejaan dalam tulisan siswa SD di Kabupaten Lamongan meliputi kesalahan penulisan kata dasar, kesalahan pemakaian huruf kapital, kesalahan penulisan awalan, kesalahan penulisan preposisi, kesalahan penulisan singkatan, dan kesalahan pemakaian tanda baca (titik dan hubung). Temuan penelitian Ghufron ini memang lebih lengkap daripada temuan penelitian ini. Jenis kesalahan yang ditemukan lebih bervariasi. Hal ini terjadi karena sumber data penelitian berupa tulisan siswa terdiri atas berbagai jenis teks dengan jumlah subjek penelitian yang lebih banyak daripada penelitian ini. Perbedaan temuan penelitian Ghufron dengan temuan penelitian ini terletak pada adanya kesalahan penulisan awalan dan kesalahan pemakaian tanda hubung.

Hasil penelitian Gunawan (2017) dan Wijayanti (2016) menghasilkan temuan yang sama. Kedua penelitian tersebut menyimpulkan bahwa kesalahan ejaan pada makalah mahasiswa Prodi Pendidikan Ekonomi dan skripsi mahasiswa PGSD terdiri atas (1) kesalahan pemakaian huruf kapital, (2) kesalahan penulisan kata depan di dan ke, (3) kesalahan pemakaian tanda baca (titik, titik dua, koma, hubung, dan tanya). Temuan Gunawan dan Wijayanti ini memiliki persamaan dengan penelitian ini pada kesalahan pemakaian huruf kapital, kesalahan penulisan kata depan, kesalahan pemakaian tanda titik, dan kesalahan pemakaian tanda koma. Adapun perbedaannya adalah dalam penelitian Gunawan dan Wijayanti tidak ditemukan kesalahan penulisan kata dasar dan kesalahan penulisan singkatan, namun jenis kesalahan tanda baca lebih beragam. Keberagaman itu terjadi karena adanya kesalahan pemakaian tanda titik dua, tanda hubung, dan tanda tanya yang tidak ditemukan dalam penelitian ini.

\section{Kesalahan Kalimat dalam Surat Izin Siswa}

\section{a. Kalimat Tidak Gramatikal}

Kalimat tidak gramatikal adalah kalimat yang tidak memenuhi kaidah penyusunan kalimat karena tidak bersubjek, tidak berpredikat, atau tidak berobjek/berpelengkap (Ghufron, 2015: 90). Berikut ini beberapa kalimat tidak gramatikal dalam surat izin siswa.

(24) Atas kami ucapkan terima kasih. (28/K/NUM)

(25) Terima kasih atas pemberitahuan saya. (29/K/REP)

Data kalimat (24) merupakan kalimat tidak gramatikal karena tidak bersubjek dan tidak berpredikat. Ketiadaan subjek dan predikat pada kalimat tersebut terjadi karena kalimat tersebut 
hanya berupa penggalan kalimat yang menduduki fungsi keterangan. Agar menjadi kalimat gramatikal, kalimat tersebut harus ditambahi kata "perhatian Bapak/Ibu" sehingga menjadi "Atas perhatian Bapak/Ibu, kami mengucapkan terima kasih." Selain itu, kalimat tersebut dapat dibenarkan dengan menghilangkan kata "atas" di awal kalimat sehingga menjadi "Kami ucapkan terima kasih."

Data kalimat (25) merupakan kalimat tidak gramatikal karena tidak bersubjek dan berpredikat atau tidak berpredikat. Kalimat tersebut dapat diubah menjadi "Kami mengucapkan terima kasih atas pemberitahuan ini" atau "Kami ucapkan terima kasih atas pemberitahuan ini."

\section{b. Kalimat Tidak Hemat}

Kalimat tidak hemat yang disebut juga kalimat mubazir adalah kalimat yang menggunakan dua bentuk yang maknanya sama. Kalimat tidak hemat juga bisa terjadi karena penggunaan kata yang tidak jelas fungsi atau maknanya. Berikut ini beberapa kalimat tidak hemat dalam surat izin siswa.

$$
\begin{aligned}
& \text { Kepada yth bpk/ibu guru } \\
& \text { (07/K/AML) }
\end{aligned}
$$

\section{... karena ibuku masuk ke dalam rumah sakit. (11/K/AAP)}

Data kalimat (26) merupakan kalimat tidak hemat karena mengandung kata yang tidak jelas fungsinya. Kalimat itu dapat diubah menjadi kalimat hemat dengan menghilangkan kata "kepada" sehingga menjadi "Yth. Bpk./Ibu Guru". Data kalimat (27) merupakan kalimat tidak hemat karena menggunakan dua kata yang sama maknanya. Dua kata tersebut adalah "masuk" dan "ke dalam". Agar menjadi kalimat hemat, kata "ke dalam" harus dihilangkan sehingga menjadi “... karena ibuku masuk ke dalam rumah sakit."

Berdasarkan paparan tentang kesalahan kalimat dalam surat izin siswa, dapat disimpulkan bahwa ada dua macam penyebab kesalahan yakni kalimat tidak gramatikal dan kalimat tidak hemat. Temuan ini jauh berbeda dengan hasil penelitian Ghufron et al. (2020) yang menemukan lima jenis kesalahan kalimat dalam skripsi mahasiswa yakni (1) kalimat tidak gramatikal, (2) kalimat tidak padu, (3) kalimat tidak hemat, (4) kalimat tidak logis, dan (5) kalimat tidak cermat. Perbedaan ini memang bisa saja terjadi karena sumber data pada penelitian Ghufron adalah skripsi mahasiswa, sedangkan sumber data penelitian adalah surat izin siswa MTs. Kalimat yang disusun mahasiswa kemungkinan lebih bervariasi daripada kalimat yang disusun oleh siswa MTs sehingga kesalahannya pun lebih bervariasi.
Memang tolok ukur utama dalam menentukan kalimat yang benar dan tidak benar yang digunakan oleh peneliti termasuk penelitian ini adalah aspek gramatikal yakni aspek kelengkapan unsur kalimat terutama adanya subjek dan predikat dalam kalimat. Penelitian Utami (2018), misalnya, menyimpulkan bahwa kesalahan kalimat yang paling banyak adalah peniadaan unsur. Begitu juga penelitian Nurhayatin et al., (2018) menyimpulkan bahwa kesalahan penggunaan kalimat efektif yang paling banyak terdapat pada penggunaan struktur kalimat, ejaan, dan diksi. Tidak jauh berbeda dengan hasil penelitian Septria, Agustina, \& Ngusman Septria et al., (2018), Amir (2018), dan Nisa \& Suyitno (2017) yang masing menyatakan bahwa kesalahan kalimat bahasa Indonesia dalam teks anekdot karya siswa disebabkan oleh struktur fungsi sintaksis, kecukupan unsur kalimat, kemubaziran unsur kalimat, pilihan kata, serta tanda baca dan ejaan; Amir menyimpulkan bahwa kesalahan kalimat dalam karangan deskripsi siswa karena adanya (1) kalimat tidak logis, (2) kalimat tidak cermat, (3) kalimat tidak padu, (4) kalimat rancu, (5) kalimat tidak sejajar, (6) kalimat interferensi, (7) kalimat tidak hemat, (8) kalimat tidak gramatikal, dan (9) kalimat taksa; Nisa \& Suyitno menyatakan bahwa aspek kegramatikalan ditandai dengan tidak adanya tanda titik pada kalimat dan penggabungan dua kalimat secara langsung.

Meskipun begitu, ada juga peneliti yang tidak menjadikan aspek gramatikal sebagai tolok ukur benar tidaknya kalimat. Hasil penelitian yang tidak menemukan aspek gramatikal sebagai penyebab utama kesalahan kalimat di antaranya adalah penelitian Sainik \& Zamzani (2015) dan Yahya et al., (2018). Sainik \& Zamzani menyebutkan kesalahan diksi, frasa, konjungsi dan preposisi pada karangan yang dibuat oleh mahasiswa, sedangkan Yahya, Andayani \& Saddhono menyimpulkan bahwa kecenderungan kesalahan kalimat pada karangan pelajar BIPA adalah diksi, ejaan, dan konjungsi yang tidak tepat.

\section{KESIMPULAN}

Dalam penelitian ini terdapat dua pokok pembahasan yakni kesalahan ejaan dan kesalahan kalimat.

Berdasarkan analisis data penelitian, dalam surat izin siswa MTs Al-Muslimun Kawistolegi terdapat kesalahan ejaan berupa kesalahan penulisan kata dasar, kesalahan pemakaian huruf kapital, kesalahan penulisan kata depan, kesalahan penulisan singkatan, dan kesalahan pemakaian tanda baca titik dan koma. 
Kesalahan kalimat yang ditemukan dalam penelitian ini adalah kalimat tidak gramatikal karena tidak adanya subjek dan predikat dan kalimat tidak hemat karena adanya kata yang tidak jelas fungsinya serta adanya dua kata yang sama maknanya sama.

\section{REFERENSI}

Amir, S. P. (2018). Analisis Kesalahan Kalimat dalam Karangan Deskripsi Siswa Kelas VII MTs Nurul Islam Bondowoso.

Apriliana, A. C., \& Martini, A. (2018). Analisis Kesalahan Ejaan Dalam Karangan Narasi Pada Siswa Kelas V Sekolah Dasar Kecamatan Sumedang Selatan. Primary: Jurnal Pendidikan Guru Sekolah Dasar, 7(2), 227. https://doi.org/10.33578/jpfkip.v7i2.6267

Arikunto, S. (2013). Prosedur Penelitian:Suatu Pendekatan Praktek. Rineka Cipta Jakarta, Indonesia.

Ariningsih, N. E., Sumarwati, S., \& Saddhono, K. (2012). Analisis Kesalahan Berbahasa Indonesia dalam Karangan Eksposisi Siswa Sekolah Menengah Atas. BASASTRA, 1(1), 130-141.

Ayudia, A., Suryanto, E., \& Waluyo, B. (2017). Kesalahan Penggunaan Bahasa Indonesia dalam Laporan Hasil Observasi Siswa Sekolah Menengah Pertama. BASASTRA, 5(2), 1-16.

Fajarya, N. (2017). Analisis Kesalahan Penggunaan Ejaan dalam Karangan Narasi Siswa Kelas X SMA Swasta Taman Siswa Binjai Tahun Pembelajaran 2016/2017. Basastra: Jurnal Bahasa, Sastra, Dan Pengajarannya, 1(2), 70 79.

https://media.neliti.com/media/publications/54 031-ID-analisis-kesalahan-penggunaan-ejaandala.pdf

Ghufron, S. (2015). Kesalahan Berbahasa: Teori dan Aplikasi. Penerbit Ombak.

Ghufron, S. (2017). Kealahan Berbahasa Siswa Sekolah Dasar di Kabupaten Lamongan. Bastra, 4(1), 31-50.

Ghufron, S., Kasiyun, S., \& Hidayat, M. T. (2020). Kesalahan Kalimat Bahasa Indonesia dalam Skripsi Mahasiswa. Belajar Bahasa, 5(1), 5162.

Gunawan, H. I. (2017). Analisis Kesalahan Ejaan pada Makalah Mahasiswa Pendidikan Ekonomi Fakultas Keguruan dan Ilmu Pendidikan Universitas Pamulang. EDUKA:
Jurnal Pendidikan, Hukum, Dan Bisnis, 2(2), $1-7$.

Hamlan, K., \& Karim, A. (2018). Analisis Kesalahan Kata Pada Karangan Deskripsi Siswa Kelas VIII SMP Negeri 1 Banawa Kabupaten Donggala Sulawesi. Jurnal Bahasa Dan Sastra, 3(3), 1-12. http://jurnal.untad.ac.id/jurnal/index.php/BDS/ article/view/10053

Keraf, G. (2004). Komposisi: Sebuah Pengantar Kemahiran Bahasa. Nusa Indah.

Mahsun. (2012). Metode Penelitian Bahasa: Tahapan Strategi, Metode dan Tekniknya. Raja Grafindo.

Nisa, K., \& Suyitno, I. (2017). Kesalahan Penggunaan Bahasa Indonesia dalam Teks Terjemahan Mahasiswa. BASINDO: Jurnal Kajian Bahasa, Sastra Indonesia, Dan Pembelajarannya, 1(1), 1-13.

Nurhayatin, T., Inggriyani, F., \& Ahmad, A. (2018). Analisis Keefektifan Penggunaan Kalimat Dalam Karya Tulis Ilmiah Mahasiswa Pendidikan Guru Sekolah Dasar. Jurnal Pendidikan Sekolah Dasar, 4(1), 102. https://doi.org/10.30870/jpsd.v4i1.2911

Prasetya, A. D. A. (2019). Analisis Kesalahan Ejaan dan Pilihan Kata pada Surat Dinas di STKIP Al Hikmah Surabaya. Lingua Franca: Jurnal Bahasa, Sastra, Dan Pengajarannya, 3(1), 120-127.

Qhadafi, M. R. (2018). Analisis Kesalahan Penulisan Ejaan yang Disempurnakan dalam Teks Negosiasi Siswa SMA Negeri 3 Palu. Jurnal Bahasa Dan Sastra, 3(4), 1-21.

Sainik, P. C., \& Zamzani, Z. (2015). Analisis kesalahan kalimat pada karangan berbahasa indonesia mahasiswa di Jawaharlal Nehru University New Delhi, India. LingTera, 2(1), 51-60.

Septria, F., Agustina, A., \& Manaf, N. A. (2018). Kesalahan Kalimat Bahasa Indonesia dalam Teks Anekdot Karya Siswa Kelas X SMAN 1 Gunung Talang Kabupaten Solok. Pendidikan Bahasa Indonesia, 5(2), 109-116.

Sugiyono. (2016). Pedoman Umum Ejaan Bahasa Indonesia. Badan Pengembangan dan Pembinaan Bahasa Kementerian Pendidikan dan Kebudayaan.

Sugiyono. (2017). Metode Penelitian Bisnis: Pendekatan Kuantitatif, Kualitatif, Kombinasi, dan $R \& D$. Penerbit CV. Alfabeta: Bandung. 
Tarigan, H. G. (2008). Menulis sebagai suatu keterampilan berbahasa (Edisi Revisi). Bandung: Angkasa.

Utami, P. S. N. (2018). Analisis kesalahan keefektifan kalimat pada teks biografi karangan siswa kelas VIII SMP Negeri 158 Jakarta. Jurnal AKSIS: Jurnal Pendidikan Bahasa Dan Sastra Indonesia, 2(2), 190-201.

Wijayanti, A. Y. W. (2016). Analisis Penggunaan Ejaan pada Skripsi Mahasiswa PGSD Universitas Islamic Centre Sudirman GUPPI Undasari. 10(2), 184-198.
Yahya, M., Saddhono, K., \& others. (2018). Studi kesalahan penulisan kalimat dalam karangan pelajar bahasa Indonesia untuk penutur asing (BIPA). Dialektika: Jurnal Bahasa, Sastra, Dan Pendidikan Bahasa Dan Sastra Indonesia, 5(1), 1-20. 